Vacant land in London: a planning tool to create land for growth.

Author: Sonia Freire Trigo*

Bartlett School of Planning, University College London (UCL), London, UK

Bartlett School of Planning

University College London

Fifth Floor

Central House

14 Upper Woburn Place

London

WC1H 0NN

sonia.freire.trigo@ucl.ac.uk

*corresponding author 


\title{
Vacant land in London: a planning tool to create land for growth.
}

\author{
Vacant land is a widespread urban phenomenon that has been problematised as a waste \\ of a scarce resource, which needs to be brought back to use. The consensus around this \\ belief has been almost unanimous, despite the contradiction between the idea of \\ scarcity and that of vacancy. This paper explores the assumptions underpinning this \\ contradiction to point to new ways of addressing the 'vacant land problem'. Drawing \\ on the work of Lefebvre and Massey, the paper suggests a dialectical framing of vacant \\ land to understand how its socially constructed nature shapes its transformation. The \\ paper reveals a static understanding of urban change behind the conceptualisation of \\ Battersea Power Station and Silvertown Quays as 'bad places', which in turn \\ legitimises and shapes their transformation. The paper argues for a re-problematisation \\ of 'vacant land', whereby its function as a planning tool for growth can be challenged.
}

Keywords: vacant land; land scarcity; Lefebvre; Massey; London.

\section{Introduction}

"The way we think about space matters. It inflects our understandings of the world, our attitudes to others, our politics." (Massey 2005)

Vacant land is a widespread urban phenomenon that has been studied in different contexts, both in the Global North and the Global South (Pearsall and Lucas 2014). Underpinning all these studies is the belief that (urban) land is a valued, valuable, and finite resource and its 'best use' is of paramount importance to the environment, social, and economic realms (Bennett 2017). The re-use of vacant land comes as a reasonable and necessary political choice in this light. The way forward seems less clear.

One of the reasons for that is the difficulty to pin down the very object of analysis. For example, in England, the problem of 'vacant urban land' has been widely studied since the mid-1970s, when the industrial decline of the country led inner city areas to an unacceptable run-down situation (Home 1983, Kivell 1993). A considerable number of land surveys, policy reports, and research studies have tried to grasp the problem of urban vacant 
land and provide adequate solutions for it. However, a historical overview of these documents highlights the continuous changes to the vacant land definition (see Table 1), which makes any attempt to monitor and address the phenomenon almost impossible. More importantly, the review calls into question the very nature of 'vacant land', portrayed in surveys and policies as a measurable object. However, the changes to the definition of vacant land over time suggests that there is more to it than just a piece of empty land.

This paper takes on the epistemological challenge behind the blurred nature of vacant land and explores how it relates to wider debates about land transformation and land scarcity. In so doing, it suggests the need for a dialectical approach to vacant land, where its complex nature would be fully acknowledge in the analysis. Drawing on Lefebvre's and Massey's dialectical take on the production of space (in particular Lefebvre 1991 [1974], Massey 2005), the paper presents vacant land as the product of the interactions between the physical, the personal, and the regulatory dimensions of vacant land. The paper then illustrates those interactions through a comparison of two long-standing vacant sites in London, Battersea Power Station and Silvertown Quays. The thematic analysis of the semi-structured interviews highlights the 'multiplicity of stories' (Massey 2005) around vacant land and its transformation, which illustrates the 'conflicts immanent to space' (Lefebvre 1991 [1974]) bounded up with any land transformation process. More importantly, the analysis reveals that the static conceptualisation of urban change, embedded in the regulatory dimension of vacant land, determines its socially constructed nature and the way its transformation is delivered on the ground.

The paper concludes that the static and growth-led conceptualisation of urban change, embedded in the regulatory framework, are primarily responsible for the way vacant land is perceived and mobilised. As the cases illustrate, the static and growth-led idea of change leads to a portrayal of Silvertown and Battersea as 'bad places', which legitimises their large- 
scale transformation as a necessary step to turn them into 'good places'. The filtering of certain voices and interests in the process emerges as a necessary strategy in the pursuit of a pre-established end (the good place), which is more responsive to expected demands than to existing needs. Vacant land emerges in this light as a powerful planning tool, a sort of 'reboot button', at the service of a political and economic agenda that employs land transformation as the key factor to bring about economic growth.

The following sections explore in more detail the ideas presented in this introduction. The first part explores the three assumptions behind the seemingly impossible marriage between land scarcity and vacant land: the objective nature of vacant land; the static understanding of urban change; and the growth-led agenda embedded in the institutions that mediate land scarcity. The second part discusses the dialectical conceptual framework to overcome the limitations of the previous assumptions in the study of vacant land. The third and fourth parts illustrate the previous theoretical discussion through the comparison of Battersea Power Station and Silvertown Quays. Drawing on the findings from the cases, the fifth part presents the conclusions of the paper.

\section{The Assumptions Underpinning the Vacant Land Problem}

\section{The nature of vacant land}

The literature shows that, for the last 50 years, monitoring the extent, location, and changes to vacant land has been a primary concern for local, regional, and central governments in England. Carrying out a longitudinal analysis of vacant land over time has been a fundamental objective in the public sector's effort to grasp the problem and devise the right mechanisms to address it. Unfortunately, such endeavour has failed to provide a definitive answer to the problem due to constant changes in the vacant land definition (see Table 1). 


\section{[Table 1 near here]}

A detailed analysis of these definitions, included in my thesis research, suggests that the complex nature of vacant land is the reason that makes this object of study so elusive. The range of 'different types' of vacant urban land traced over time shows that, far from being just a problematic physical entity, vacant urban land is a social construct highly influenced by its context. The review shows that the way society thinks about the (re)use of land in the built environment shapes urban land policies, which in turn determine the definition of vacant land (Adams, De Sousa, and Tiesdell 2010). In other words, vacant land emerges in this review as complex phenomenon that entails a physical nature, but also a social one that varies over time and is responsible for the constant changes to its definition.

The positivist approach of land use surveys is unable to capture the social nature of vacant land. Such approach rests on the assumption that economic and social processes can be unproblematically translated into a system of objective and fixed land use categories (Perin 1977, Healey and Barrett 1990). However, the constant changes to the vacant land definition prove otherwise. As a result, the public sector's attempts to monitor vacant land have never been able to offer a comprehensive picture of this phenomenon, which has usually been cited as the main reason for the failed policies on vacant land (see for example CPRE 2016).

There have also been attempts to grasp the vacant land phenomenon from an agencybased perspective (see for example Alker, Joy, et al. 2000, CABERNET 2006, Dixon, Otsuka, and Abe 2011, Doak and Karadimitriou 2007, Alker, Barrett, et al. 2000). In these cases, the impact of stakeholders' different interests in the redevelopment process of brownfield land ${ }^{1}$ takes centre stage. Interestingly, the potential impact of these interests on

\footnotetext{
${ }^{1}$ Brownfield land is the common term currently used to refer to vacant land in England.
} 
the very definition of vacant land is not considered in most of these studies, which usually create their own composite definition drawing on other positivist vacant land definitions. The work of Doak and Karadimitriou (2007) stands out as an exception. Using a combination of complexity and networks theories, the authors suggest a conceptual framework that presents 'brownfield land' as a social construct, born out of the interaction between the networks of actors involved in the transformation of that land (Doak and Karadimitriou 2007). They also explain how that concept recursively shapes the networks' strategies for the transformation of those brownfield sites (Doak and Karadimitriou 2007).

Doak and Karadimitriou therefore emphasise the socially constructed nature of vacant land and the need for an approach that fully takes into account the complex nature of this phenomenon (see also Karadimitriou, Doak, and Cidre 2010). Unfortunately, the paper remains at a theoretical level and does not illustrate the production of the concept and its influence on the networks. Nevertheless, the authors highlight the complex nature of the vacant land problem and the need to for a constructivist approach to this phenomenon, an approach also shared in this research.

\section{Time and the transformation process of vacant land.}

There is also a wealth of studies that are not concerned with the nature of vacant land, but with the production process that generates long term vacant sites (see for example Burrows 1977, Nicholson 1982, MacGregor et al. 1985, Couch and Fowles 1992). These studies do not see vacant land as a problem per se, but just as an unavoidable transient feature of the built environment (Nicholson 1982). Vacant land, in their view, is not a fixed category of land but one product of land transformation. The problem, they argue, lies in the different factors impinging on the 'normal flow' of that process, which could turn that transient feature into a long term one (Fig. 1).

[Figure 1 near here] 
The length of vacancy has been mainly approached from two different perspectives: urban economic theory and property development theory (Cameron, Monk, and Pearce 1988, Henneberry 2017). While the first approach has primarily focused on the economic reasons linked to the cessation of use and the re-use of land, the second approach has been mostly concerned with the factors impinging on the transformation process between those two moments. In any case, the review of the studies within each approach highlights two shortcomings. First, the studies share what Doreen Massey calls a time-less understanding of space (Robins, Edwards, and Massey 2001, Massey 2005). The studies portray the transformation of vacant land either as a temporal ellipsis between the 'cessation of use' and the moment of 're-sue' (the case of Burrows, 1977, 1978); or as a fleeting moment that demarcates 'short term' from 'long term' vacant land (e.g. Markowski 1978, Couch and Fowles 1992); or as a circular and repetitive process that begins and ends with the same 'cessation of use' stage, without taking any notice of the impact that previous changes might have on it (e.g. Nicholson 1982, MacGregor et al. 1985). In all of them, change is reduced to a fixed sequence of self-contained, independent stages, with clear start and end points. Change is modelled as a 'closed-system', with no room for unexpected events to alter the connection between the stages or the end result of the process (Massey 1999, Massey 2005).

This static understanding of change is behind the second theoretical shortcoming of the studies. The conceptual models are unable to bring together the different levels of analysis of the phenomenon - the empirical and the contingent on the one hand, and the conceptual and the general on the other hand (Healey 1992, Massey 1993, Guy and Henneberry 2000). Accordingly, the models can only offer partial explanations and solutions for the vacant land phenomenon, which are too contingent to be replicated or too abstract to be of any use. 


\section{Land scarcity and vacant land}

The literature review has also revealed a common assumption persistently underpinning the land use surveys and studies of vacant land in England: that vacant land is a waste of a scarce resource and, consequently, it needs to be brought back to productive use. This 'productive stance' on land has always been used as a starting point for the theoretical discussions around vacant land. But the implications of this argument for the way vacant land is conceived and addressed have never been fully explored. This section addresses this issue.

In this 'productive stance' on land, land matters as "physical space for economic activities" (Ryan-Collins, Lloyd, and Macfarlane 2017, 5), as nothing more than a support for the uses that will take place on it. The 'productive stance' therefore brings into competition actors with different views about the economic activities that could take place on land. The resulting land use pattern therefore reflects the choices made in the mediation of that competition over land. In this light, the scarcity of land as 'physical space' reveals its political nature (Hartmann and Gerber 2018). Land use planning and land markets play a crucial role in the regulation of competition over land (Oxley 2004, Needham 2006, Hartmann and Gerber 2018). To understand where vacant land stands in relation to land scarcity, attention should be paid to these institutions.

A close look at land markets and land use planning shows that the mediation of competition over land happens in two ways. First, it happens through a distinction between 'rights in land' and 'legitimate interests in land', which sets the boundaries to claims over land from the outset. There are many different types of 'rights in land', which vary according to the legal systems that operate in each context (Needham, 2006). Nevertheless, these types largely fall into three groups in the English context: the right to use the land in exclusivity for an unlimited period of time (i.e. freehold); the transferred rights to use the land in exclusivity for a limited period of time and under the conditions agreed with the landowner (i.e. 
leasehold); and the right to change the use of land (i.e. development right) (after Needham 2006). As for the 'legitimate interests' in land, the English land use planning system recognises two types: the 'legitimate interests' of those that are affected by the transformation of land, but do not have any rights over it; and the 'legitimate interests' of those who also lacks rights in land, but have a direct input in the preparation of the planning applications associated with any land transformation proposal (after Oxley 2004, Cullingworth et al. 2015). These different rights and interests ultimately reveal the voices that land markets and land use planning recognise in the transformation process of land, which in this paper have been named as Landowners, Tenants, Regulators, the Affected, and the Mediators. The extent to which each of these voices determines the outcome of a land transformation process therefore reveals the type of rights or interests that is more prevalent in the mediation of the conflict over land.

The second way in which land markets and land use planning mediate the competition over land is through the land allocation process and the planning framework, which in England is the National Planning Policy Framework (NPPF). Land for new uses is allocated in Local Plans according to a prior assessment of 'need' for those uses (DCLG 2012, 2014). Interestingly, the NPPF does not establish the meaning of 'need'. More importantly, it sometimes uses the term as an equivalent for 'demand' (articles 159 and 161, DCLG 2012). The confusion between 'need' and 'demand' has been identified as one of the main problems in the calculations that underpin the land allocation process (Adams and Watkins 2002). Moreover, estimating 'need' is a complex task because there are no clear signs for it, contrary to demand for goods, which can be estimated from their price. Consequently, assessment of need largely depends on the assumptions about population growth, household formations, etc., which entail political rather than purely technical decisions about the future. 
The land allocation process in England therefore reveals itself as "a political fix supported by evidence" (Gallent, Hamiduddin, and Madeddu 2013) that conceals a political agenda behind an 'objective' methodology. Instead of mediating an objective discussion about the use of scarce resources, the NPPF and the land allocation process have become tools for generating economic growth (Rydin 2013, Bowie 2017). Competition for land in this growth-led planning exclusively favours transformations that yield 'high' land use values (Rydin 2013, Bowie 2017).(Rydin 2013, Bowie 2017, DCLG 2012, 2014, Gallent, Hamiduddin, and Madeddu 2013, Crosby, McAllister, and Wyatt 2013) Other 'low' land use values such as manufacturing industries or small retail spaces are therefore bound to disappear eventually (see for example Ferm and Jones 2015). This logic explains the paradigm shift of the vacant land concept, which has moved from being a 'problem' to being an 'opportunity' (Adams, De Sousa, and Tiesdell 2010, Karadimitriou, Doak, and Cidre 2010) (Gallent, Hamiduddin, and Madeddu 2013, Murdoch and Abram 2002)In other words, the growth-led agenda that also shapes the regulatory framework is now embedded in the vacant land definition.

\section{A Dialectical Approach to Vacant Land}

Taking stock on the discussions from the previous section, the paper argues for a different framing of the vacant land phenomenon. Instead of wondering about the features that characterise vacant land, or the factors that affect the length of vacancy, the previous discussions highlight the need to understand how 'vacant land' is socially constructed and how such construct affects the transformation of 'vacant sites'. To explore the production of the vacant land construct, The paper employs a conceptual framework that draws on the work Henri Lefebvre and Doreen Massey (in particular Lefebvre 1991 [1974], Massey 2005). 
Lefebvre argues that Space can only be grasped as the product of a trialectics process(Lefebvre 1991 [1974]). Drawing on Hegel's dialectical thinking ${ }^{2}$, as well as Marx's materialism critique of Hegel (Marx 1990 [1873]), and Nietzsche's concept of the 'eternal return' (Nietzsche and Kierkegaard 2007), Lefebvre presents Space as the ever-changing product of a dialectical relation between the 'general' (i.e. Mental Space), the 'singular' (i.e. Natural Space), and the 'particular' (i.e. Social Space) (Lefebvre 1991 [1974]). In this trialectic approach, Space is not portrayed as a final product, but as an ongoing process of production. In this way, Lefebvre's trialectics (Fig.2) provides a dynamic account of space, whereby time becomes intertwined with it, albeit distinct.

\section{[Figure 2 near here]}

Lefebvre's dialectical analysis of space resonates with the key findings from the previous section. First, Lefebvre's account of space acknowledges the connection between the materiality of the world and the way we think about it, which is in line with calls for a constructivist understanding of the vacant land phenomenon. Second, he conceives space as a process in constant evolution, rather than a final product. In this way, Lefebvre's trialectics bring together space and time to offer a dynamic account of transformation that could overcome the limitations of previous vacant land models. Finally, his trialectics call attention

\footnotetext{
${ }^{2}$ Hegel elaborates a new method of thinking to be able to grasp the Absolute Truth, or Concrete Universals, of the world around us. This new method, called dialectical thinking, differs from the Aristotelian logic in that the negation of the thesis (i.e. anti-thesis) does not reinstate the original thesis. For instance, 'A is not non-A' provides an example of Aristotelian reasoning. But in Hegel, the anti-thesis would actually allow a move towards a new rational unity: the synthesis. In other words, 'A is not non-A' would render the Concept that reflects both A and non-A. The synthesis (Concept) overcomes and preserves the elements of thesis (A) and antithesis (non-A). According to Hegel, this way of thinking would allow us to achieve the Absolute Truth, because it would help us to grasp the whole without losing sight of its constitutive parts (Navarro Cordón and Calvo Martínez 1992)
} 
upon the social reality of space to understand the "conflicts immanent to space" (Lefebvre 1991 [1974], 365). Once again, this resonates with the attention paid in the previous section to the agency of stakeholders in the conceptualisation and approach to vacant land, as well as the role of the regulatory framework in the mediation of conflicts between different agents. For these reasons, the paper suggests a conceptual framework (Fig.3) that adopts Lefebvre's dialectical analysis of Space (Fig.2).

\section{[Figure 3 near here]}

In this dialectical framework, vacant land is constructed out of the interaction between the natural reality of vacant land, its mental reality, and its social reality. The mental reality corresponds with the 'brownfield land' concept, which encapsulates the growth-led logic of the regulatory system. The natural reality of vacant land corresponds with those brownfield sites that have been allocated for development in the Local Plans. Finally, the social reality of vacant land has a less straightforward equivalence than the other two. Lefebvre suggests that to grasp Social Space we should look at its material expressions ${ }^{3}$ and trace their evolution from the past to the present, which would then help us understand the future direction of Social Space (Lefebvre 1991 [1974]).. But this methodology reduces time to its historical form, to a linear sequence of spatial manifestations (Massey 2005, Valverde 2014). The past, the present, and the future appear in this methodology as a closed system "where all the interconnections have been established" (Massey 1999, 2).

However, if social space is the product of social relations, then it contains a multiplicity of potential trajectories that render the future open (Massey 1999, Massey 2005). Similarly, the past should also be understood as a multiplicity of coexisting trajectories in

\footnotetext{
${ }^{3}$ Lefebvre argues that there are three 'material expressions' of Social Space: Spatial Practices, Representation of Spaces, and Representational Spaces (Lefebvre 1991 [1974], 38-41).
} 
competition to move forward. Accordingly, the production of social space cannot be told in a grand narrative that ignores the influence of other non-materialised trajectories on the resulting space. Instead, the narrative of the production of space should entail the "simultaneity of stories-so-far" (Massey 2005, 9) that reflects all those coexisting trajectories over time. The research therefore suggests a shift in Lefebvre's analysis of social space: from looking at its material expressions that provide a grand narrative, to focusing on the personal experiences of those voices (i.e. Landowners, Tenants, Regulators, Mediators, and Affected) involved in the transformation of a site (a 'brownfield site') over time.

The vacant land construct (Fig.3) emerges as the product of a trialectic interaction between the brownfield concept, the brownfield site, and the experiences of the individuals connected to the transformation of that site. In this way, the model brings together the different levels of analysis of the vacant land problem: the contingent (i.e. concrete brownfield sites) and the general (i.e. the dialectical process). Moreover, the model portrays time as a continuous flow in which the interaction of the three dimensions take place. Accordingly, vacant land is not presented as a necessary start and end point of a predetermined process of transformation, but as an entity in constant transformation.

\section{Vacant land constructs in London}

To illustrate the production of the vacant land construct in London, the research has adopted the concept that the regulatory framework uses to refer to the generic term 'vacant land' in this current context - i.e. 'brownfield land'. For this reason, the paper will refer to 'vacant land' or 'brownfield land' indistinctively from this point forward. The selection of the case studies therefore looked for those sites in London that are considered 'brownfield sites' in the London plan. From the multiple examples available in the London Plan, the research carried out an informed selection to meet the 'replication logic' of a multiple case study 
strategy (Yin 2014). The resulting sites are Battersea Power Station and Silvertown Quays (Fig.4).

[Figure 4 near here]

The history of Battersea Power Station perfectly captures Massey’s temporal take on space, which she describes as the product of co-existing 'stories so far' (Massey 2005). In Battersea, different plans and aspirations have co-existed in the transformation of the site over time, from its days as low land for agriculture, to its days as the place of the renown Battersea Power Station, to its days of dereliction, and to its current transformation process (see for example Saint 2013, Watts 2016). Each period reveals how the materialised uses always came out of a competition between different interests on land. The interviews focused on the last chapter of Battersea's long history, which concerns the project of the current owners, a Malaysian consortium that bought the site back by end of 2012 (Fig. 5).

\section{[Figure 5 near here]}

The Outline Planning application for the whole development, delivered by the previous owners, Treasury Holdings, was granted approval in August 2011 (Watts 2016). When the Malaysian consortium took over the site, they stuck to the existing Outline application but introduced changes to the subsequent Reserved Matters applications, which contained detailed information for each of the seven development phases. The Outline describes a mixed-use scheme (Fig. 6) that will provide around 3,200 residential units (London Borough of Wandsworth 2011) and 17,000 jobs (BPSDC 2017). It will also contribute to the construction of the Northern line extension (a new branch of the underground transport system), the construction of the Thames Water Tideway tunnel (commonly known as the new 'super sewage'), and the complete refurbishment of the power station (London Borough of Wandsworth 2011). The site hosted a series of temporary events 
since its definitive closure in 1983 (Wandsworth 2011; Watts 2016). However, there were no temporary uses left on the site at the time the interviews were carried out.

[Figure 6 near here]

The history of Silvertown Quays provides a similar account of co-existing and conflicting aspirations over time: from its days as marsh land, to its days as a busy maritime commerce enclave between the Empire and its colonies, to its days of rapid decline in the 1970s and 1980s, to its latest transformation project (see for example Brownill 1993 [1990], Royal Docks Management Authority (RoDMa) 2015). In this case, the interviews also focused on the current transformation process, where the Greater London Authority (GLA) (i.e. the landowners), have chosen a development partner to carry out the project.

\section{[Figure 7 near here]}

The Outline Application for the current project was granted approval in August 2016 (London Borough of Newham 2015). The applicant is the Silvertown Partnership LLP (TSP), a company that comprises Chelsfield Properties, First Base, and Macquarie Capital (The Silvertown Partnership 2018). The outline proposal (Fig.8) comprises a site of $27.4 \mathrm{Ha}$ to be developed in seven phases. This new urban centre is expected to generate around 20,000 jobs and provide 3,000 new homes, with 35\% of them affordable (London Borough of Newham 2015). The site comprises some existing industrial businesses on the south east corner of the site. Although the plans include the redevelopment of this area, the comments to the application indicates opposition from at least one tenant to leave the site (London Borough of Newham 2015). Unfortunately, the tenants did not want to take part in this research.

\section{[Figure 8 near here]}

Both Battersea and Silvertown are located within two different Opportunity Areas in London. Opportunity Areas are described in the London Plan as: 
"the capital's major reservoir of brownfield land with significant capacity to accommodate new housing, commercial and other development linked to existing or potential improvements to public transport accessibility. Typically they can accommodate at least 5,000 jobs or 2,500 new homes or a combination of the two, along with other supporting facilities and infrastructure" (Mayor of London 2016, 66 emphasis added).

In addition, the Glossary of the London Plan (2016) provides the following definition of 'brownfield land':

"Both land and premises are included in this term, which refers to a site that has previously been used or developed and is not currently fully in use, although it may be partially occupied or utilised. It may also be vacant, derelict or contaminated. This excludes open spaces and land where the remains of previous use have blended into the landscape, or have been overtaken by nature conservation value or amenity use and cannot be regarded as requiring development.” (Mayor of London 2016, 407-408)

Both definitions reveal how the growth-led agenda is embedded in the concept of 'brownfield land' in London. These 'brownfield sites' are not necessarily empty, as the second definition reveals. They are allocated for development because they have the capacity to bring about the level of growth expected in an Opportunity Area (i.e. 5,000 jobs or 2,500 new homes or a combination), as both Outline Applications prove. The land allocation process therefore establishes a direct connection between the mental reality of 'brownfield land', determined by a growth-led agenda, and its physical reality. In other words, the sites are 'brownfield sites' because they provide enough physical space for the allocation of land uses needed in London - i.e. residential uses.

To explore the individual experiences of these sites and their conceptual dimension, the research carried out a total of 38 semi-structured interviews. These interviews tried to cover all the voices and interests recognised in the regulatory framework (i.e. Landowners, Tenants, Regulators, Mediators, the Affected). However, the voice of the Tenants was not 
part of the analysis in the end because there was no one available for an interview, as explained above. The questions asked to the different actors included in each group of voices revolved around their experiences of the sites and their transformation process. The thematic analysis of the answers regarding the experiences of the sites (i.e. Narratives of the Site) illustrates how the mental and the physical dimensions of 'brownfield land' shape its social dimension. In other words, the analysis of the Narratives of the Site explains the production of the vacant land construct in London. On the other hand, the thematic analysis of the answers regarding the experiences of the process (i.e. Narratives of the Process) illustrates how the construct affects the way the transformation takes place. In both case studies, the analysis reveals alignments and misalignments between the groups' Narratives, which illustrate the existing consensuses and conflicts surrounding each brownfield site. Or as Lefebvre put it, "the conflicts immanent to space" (Lefebvre, 1991 [1974]:365).

For the sake of brevity, the steps taken to conduct the thematic analysis of the interviews have not been included in this paper. Nevertheless, it is worth explaining the meaning of 'theme'. A theme represents a pattern of meanings shared across a group (Braun and Clarke 2006). In this research, the themes provide the groups' shared experience about the phenomenon of study - the vacant sites of Battersea Power Station and Silvertown Quays. These themes therefore illustrate the way each voice in the regulatory framework (i.e. Landowners, Regulators, Mediators, the Affected) produces their own vacant land construct (Table 2). The comparison across the groups' themes in each case study, and between the themes of the two vacant sites, allows the research to explain the production of the vacant land construct in London.

\section{[Table 2 near here]}

This comparison reveals that all the different constructs can be group in two modes of production: a dynamic one, underpinning the constructs of the Affected in both case studies; 
and a static once, which underpins the constructs for the rest of the groups. The dynamic vacant land construct of the Affected portrays the past, the present, and the future as a continuous flow where change leave a mark that shapes whatever comes next. For example, the Affected in Silvertown Quays lack past experiences of the Docks. The closure of the Royal Docks triggered a mass migration of workers to Essex and wiped out the memories of the Dock's thriving past. As a result, the Affected understand Silvertown in the present as a place with no meaning for them, as a sign of disregard towards them. Their negative experiences of the past and the present make them hopeful and fearful about the future Silvertown Quays. They acknowledge the positive physical impact that the transformation will bring about, but they believe they will not benefit from it because disregard is what the site symbolises for them. In their narrative, the ambivalent future is shaped by the past and the present to a certain extent, but it remains open.

Conversely, the constructs of the rest of the groups are static products. Mediators, Regulators, and Landowners treat the past, present, and future as independent stages. Time does not flow from past, to present, to future; they do not affect each other. Time is conceived as a series of independent stages, which means that they can happen in simultaneity (Massey 1999, Massey 2005). Consequently, Silvertown's construct is a Ripe Opportunity for Mediators because "now is the appropriate time" to bring about a future "new piece of city" on that empty site. Equally, Mediators portray Battersea as a New Iconic Place because they are replacing a "blank canvas" with a "new town" around an "iconic building". In both cases, past, present, and future form a closed system that portrays 'change' as a foretold story (Massey 1999, Massey 2005), where the future 'good place' is both the end and the start point for the transformation of the 'bad place'. The future shapes the present and the past, not the other way around (Abram, 2014). The process is therefore time-less (Massey 2005). 
In sum, the production of vacant land constructs in London is primarily characterised by a time-less understanding of space. As a result, past, present, and future are not treated as a continuous temporal flow, but as self-contained, independent stages. Consequently, they can be arranged in the best way to facilitate the delivery of a pre-determined end-product. In the time-less understanding of Silvertown and Battersea, past-present happens simultaneously with the future. For that reason, both sites are portrayed as 'bad places' and 'good places' at the same time, which reinforces the argument for transformation (Blomley 2004) and justifies the delivery of enormous growth on the sites.

\section{The transformation process of vacant land in London}

The comparison between the Narratives of the Process (Table 3) in both case studies reveals that the way the groups conceptualise 'change' affects the way they understand vacant land, and vice versa. For example, the negative symbol that Silvertown represents for the Affected correlates with their negative understanding and attitude towards its transformation. Similarly, the fantastic economic opportunity that Battersea represents for the Landowners also correlates with their understanding of its transformation as an ongoing process of value creation. In this way, the analysis illustrates Massey's point when she explains that "the way we think about space matters" because it determines our engagement with the world (Massey 2005). In this research, it determines the groups' engagement with the two vacant sites.

\section{[Table 3 near here]}

The analysis also shows that the groups' experiences of the process have to do with the way their social relations in land are regulated. For example, the dwelling experiences and sense of belonging of the Affected are recognised in the planning system as legitimate interests in land. However, their voice in the transformation of the sites is weak. The Affected know their voice is on the sidelines of the plan making and decision taking processes. They 
see the consultation events as a form of 'tokenism' (Arnstein 1969) and not genuine participation. As a result, they generally adopt a resigned and cynic attitude towards the transformation of the sites. This resigned attitude shapes their negative constructs and negative experiences of the transformation process (Tables 2 and 3 ). The rest of the groups show a more positive attitude that is also linked with the way their social relations in land are regulated. For example, Mediators' relations are also recognised as legitimate interests, but their voice is given a direct input in the transformation of the sites. Creating a new place becomes their main objective in their relationship with land. This positive and proactive role, in stark contrast with the role of the Affected, results in positive constructs and attitudes towards transformation. In sum, the regulatory framework emerges as a critical factor in the conceptualisation of space and time. The way it regulates social relations in land has an impact on their understanding of land and its transformation. In this way, Massey's idea works in a biunivocal way: our understanding of space (and time) shapes our politics, but our politics shape our understanding of space (and time) too.

The analysis also reveals that the static conceptualisation of transformation determines the way change is delivered on the ground. Reining in change to deliver a predetermined end product becomes the only alternative to reconcile a static understanding of the built environment with its dynamic nature. The filtering of any interest different to the ones of the end product becomes a necessary strategy in the delivery of the transformation projects. For example, the Development Agreement in Silvertown Quays, between the GLA, TSP, Newham Council, and Transport for London (TfL) provides 'fixed itineraries' (Murdoch and Abram 2002) that pre-empt discussions and therefore filter out interests that are not recognised in those documents. In this way, potential investors are ruled out from the process if their investment interests are not in line with the end product of the Development Agreement. Community consultation processes are also another way to filter out interests. 
For example, Battersea's development company (an actor included in the group of Mediators) set up their own community group to liaise with the community, the Battersea Power Station Community Forum (BPSCF). However, access to this group is by invitation only and this process is managed by a public relations company (i.e. Cascade Communications). Members of other very critical community groups - i.e. Battersea Power Station Community Group (BPSCG) - complained about being excluded from the meetings between the developer and BPSCF. Perhaps not surprisingly, the representatives of Wandsworth Council (who form part of the Regulators group) had the impression that the development had not stirred too much opposition.

The times-less understanding of the transformation process also means that the delivery of the projects is characterised by a relentless struggle to keep safeguard the end product from the changes to the context. For instance, Mediators in Silvertown talked about their constant efforts to ensure the viability of the project all the way through. Costs vary over time, not only because of changes in the economic context but also because of unexpected problems that are bound to arise in the delivery of any large-scale transformation process. However, TSP conceives Silvertown as a "business stream" where costs and income streams are in equilibrium. Consequently, things like affordable housing are pitted against things like transport infrastructure, despite their very different nature and purpose in the future site. In this way, any future raise of constructions costs would result in a likely reduction of affordable housing to keep the equilibrium between costs and income.

In all, the Narratives of the Process reveals that the static conceptualisation of transformation limits the possibilities for questioning the end product that the process is trying to achieve (Massey 1999, 2005). These possibilities are filtered out in an attempt to lead the transformation process towards a pre-determined end product. The role of the regulatory framework emerges as a crucial factor in the rolling out of this static delivery of 
change and in the way the groups understand space, through the way their relationships in land are recognised and managed.

\section{Conclusions.}

By taking a constructivist approach to the vacant land phenomenon, the research has illustrated how this land use that is not just a piece of measurable physical space, but it also bears the interests, hopes, fears, and memories of the different actors related to each vacant site. More importantly, this constructivist approach has also made evident the impact of the regulatory framework on those interests, hopes, fears and memories and how that affects the way we think about land. As the research shows, the regulation of rights and interests on land has an impact on the attitude towards land transformation, which in turn affects the way (vacant) land is conceived.

In addition, the research illustrates the profound impact of a time-less understanding of space on the way we think and act on land. The case studies show how a time-less understanding of space results in a vacant land construct dominated by its regulatory concept, in which all that matters is the scale of the site and the amount of growth it can deliver. Moreover, the time-less understanding of space has an impact on the way change is delivered on the ground. The filtering of interests and factors that could divert the process from its predetermined outcome become the necessary strategies to reconcile the dynamic reality of the built environment with its time-less understanding. The regulatory framework once again plays a crucial enabling role in this process.

Drawing on the findings from the research, this paper argues for a re-problematisation of the vacant land phenomenon. The impact of the regulatory framework on the way vacant land is constructed and mobilised, coupled with the growth-led agenda that underpins that framework, has turned the concept of 'brownfield land' in London into a powerful mechanism to create land for growth. For this reason, vacant land should no longer be looked 
at as a 'failure', but as one of the 'tools' the regulatory framework employs to bring about economic growth. Recognising the instrumentality of vacant land in the debates around scarcity and growth in London would call into question the 'objective' designation and allocation of brownfield land in the city. This in turn could help strengthen the arguments against the 'necessary' transformation of those designated 'brownfield sites', which usually contain all sort of 'low value uses' - e.g. small manufacturing industries in London - that do not conform with the growth-led agenda of the regulatory framework.

The paper finally calls for more research on ways to conceive transformation processes with open-ended outcomes. Taking this dynamic understanding of urban change, would open up the possibility to think of urban land as a product of social relations over time, rather than a mere support for activities. This would challenge the use of scale and location of a site as the key factors in the allocation process of land, which would challenge the growthled agenda of the regulatory system in turn. In such a dynamic and non-growth-led understanding of urban change, the 'problem of vacant land' would cease to exist. 


\section{REFERENCES}

Abram, Simone. 2014. "The time it takes: temporalities of planning." Journal of the Royal Anthropological Institute 20 (Supp.1):129-147. doi: 10.1111/1467-9655.12097.

Adams, David, Christopher De Sousa, and Steven Tiesdell. 2010. "Brownfield Development: A Comparison of North American and British Approaches." Urban Studies 47 (1):75-104. doi: 10.1177/0042098009346868.

Adams, David, and Craig Watkins. 2002. Greenfields, Brownfields and Housing Development. Oxford, UK: Blackwell Publishing Ltd.

Alker, Sandra, Patricia Barrett, Daniel Clayton, and Glyn Jones. 2000. "A classification scheme for brownfield sites in the United Kingdom." ConSoil 2000, Leipzig, Germany.

Alker, Sandra, Victoria Joy, Peter Roberts, and Nathan Smith. 2000. "The Definition of Brownfield." Journal of Environmental Planning and Management 43 (1):49-69. doi: 10.1080/09640560010766.

Arnstein, Sherry R. 1969. "A Ladder Of Citizen Participation." Journal of the American Institute of Planners 35 (4):216-224. doi: 10.1080/01944366908977225.

Bennett, Luke. 2017. "Forcing the Empties Back to Work? Ruinphobia and the Bluntness of Law and Policy." In Transience and Permanence in Urban Development, edited by John Henneberry. Chicester: John Wiley \& Sons.

Blomley, Nicholas K. 1994. "Moving, Leaving and Arriving." In Law, space, and the geographies of power, edited by Nicholas K. Blomley. New York: Guilford Press.

Blomley, Nicholas K. 2004. Unsettling the city: urban land and the politics of property. New York: Routledge.

Bowie, Duncan. 2017. Radical solutions to the housing supply crisis. Bristol: Policy Press.

Bowman, Ann O'M, and Michael A. Pagano. 2004. Terra incognita : vacant land and urban strategies. Washington, D.C.: Georgetown University Press.

Boyatzis, Richard E. 1998. Transforming qualitative information: thematic analysis and code development. London: SAGE.

BPSDC. 2017. "Regenerating Opportunities. Battersea Power Station Construction Employment and Skills Annual Report 2016/17." Battersea Power Station Development Company (BPSDC), accessed 04 March 2018. https://batterseapowerstation.co.uk/pdfs/55231-bps-12ppemployment-skills-report2017_stage-10.pdf.

Braun, Virginia, and Victoria Clarke. 2006. "Using thematic analysis in psychology." Qualitative Research in Psychology 3 (2):77-101. doi: 10.1191/1478088706qp063oa.

Brownill, Sue. 1993 [1990]. Developing London's Docklands : another great planning disaster? 1993 ed. London: Paul Chapman Publishing.

Bryman, Alan. 2008. Social research methods. 3rd ed. ed. Oxford: Oxford University Press. 
Burrows, John W. 1977. "Vacant urban land and its planning implications." PhD Thesis, University of London.

Burrows, John W. 1978. "Vacant Urban land: a continuing crises." The Planner 64 (1):7-9.

CABERNET. 2006. Sustainable Brownfield Regeneration: CABERNET Network Report: University of Nottingham.

Cameron, Gordon C., Sarah Monk, and Barry J. Pearce. 1988. Vacant urban land: a literature review 1976-86. Great Britain: Department of the Environment.

Clichevsky, Nora. 1999. "La tierra vacante en América Latina." Land Lines January:3.

Couch, Chris, and Steven Fowles. 1992. "Vacancy and recent structural changes in the demand for land in Liverpool." In Rebuilding the city: property-led urban regeneration, edited by Patsy Healey, Simin Davoudi, Mo O'Toole, Solmaz Tavsanoglu and David Usher. London: E \& FN Spon.

CPRE. 2016. Housing capacity on suitable brownfield land. New brownfield registers show significant increases in number and housing capacity of suitable brownfield sites in England. London.

Crosby, Neil, Pat McAllister, and Peter Wyatt. 2013. "Fit for planning? An evaluation of the application of development viability appraisal models in the UK planning system." Environment and planning B 40 (1):3-22. doi: 10.1068/b37181.

Crotty, Michael. 1998. The foundations of social research: meaning and perspective in the research process. London: SAGE Publications.

Cullingworth, J. B., Vincent Nadin, Trevor Hart, Simin Davoudi, John Pendlebury, Geoff Vigar, David Webb, and Tim G. Townshend. 2015. Town and country planning in the UK. Fifteenth edition. ed. London: Routledge.

DCLG. 2012. National Planning Policy Framework. Department for Communities and Local Government.

DCLG. 2014. "Housing and Economic Land Availability Assessment." Department of Communities and Local Government, accessed 15 August 2018. https://www.gov.uk/guidance/housing-andeconomic-land-availability-assessment.

Dixon, Timothy, Noriko Otsuka, and Hirokazu Abe. 2011. "Critical Success Factors in Urban Brownfield Regeneration: An Analysis of Hardcore Sites in Manchester and Osaka during the Economic Recession (2009-10)." Environment and Planning A 43 (4):961-980. doi: 10.1068/a43468.

Doak, Joe, and Nikos Karadimitriou. 2007. "(Re)development, Complexity and Networks: A Framework for Research." Urban Studies 44 (2):209-229. doi: 10.1080/00420980601074953.

Ferm, Jessica A., and Edward Jones. 2015. London's Industrial Land: Cause for Concern? London: University College London (UCL).

Gallent, Nick, Iqbal Hamiduddin, and Manuela Madeddu. 2013. "Localism, down-scaling and the strategic dilemmas confronting planning in England." The Town Planning Review 84 (5):563582. 
George, Henry. 1987 [1881]. Progress and poverty : an inquiry into the cause of industrial depressions and of increase of want with increase of wealth... the remedy. New York: Robert Schalkenbach Foundation.

GLA. 2012. Chelsfield 'pavilion' plans win race to transform Royal Docks.

Guy, Simon, and John Henneberry. 2000. "Understanding Urban Development Processes: Integrating the Economic and the Social in Property Research." Urban Studies 37 (13):2399-2416. doi: 10.1080/00420980020005398.

Hall, Ruth. 2011. "Land grabbing in Southern Africa: the many faces of the investor rush." Review of African Political Economy 38 (128):193-214. doi: 10.1080/03056244.2011.582753.

Hartmann, Thomas, and Jean-David Gerber. 2018. "Land, scarcity, and property rights." In Instruments of land policy: dealing with scarcity of land, edited by Jean-David Gerber, Thomas Hartmann and Andreas Hengstermann. London: Routledge.

Healey, P., and S. Barrett. 1990. "Structure and agency in land and property development processes: some ideas for research." Urban Studies 27 (Feb 90):89-103.

Healey, Patsy. 1992. "An institutional model of the development process." Journal of Property Research 9 (1):33-44. doi: 10.1080/09599919208724049.

Henneberry, John. 2017. "Introduction: Temporary Uses as Alternative Practices." In Transience and Permanence in Urban Development, edited by John Henneberry. Chicester: John Wiley \& Sons.

Hillier, Jean. 2002. Shadows of power: an allegory of prudence in land-use planning. London: Routledge.

Home, R. K. 1983. "Inner city vacant land: UK policies." Cities 1 (1):59-70. doi: 10.1016/02642751(83)90058-6.

Imrie, Robert, Loretta Lees, and Mike Raco. 2009. "London's regeneration." In Regenerating London : governance, sustainability and community in a global city, edited by Robert Imrie, Loretta Lees and Mike Raco. London: Routledge.

Joffe, Helene. 2012. "Thematic Analysis." In Qualitative research methods in mental health and psychotherapy : a guide for students and practitioners edited by David Harper and Andrew R. Thompson. Chichester, West Sussex: John Wiley \& Sons.

Karadimitriou, Nikos, Joe Doak, and Elisabete Cidre. 2010. "Rethinking Brownfields: Discourses, Networks and Space-Time Relations." In A planner's encounter with complexity, edited by Gert de Roo and Elisabete A. Silva, 263-281. Farnham: Ashgate.

Kivell, Philip. 1993. Land and the city : patterns and processes of urban change. London: Routledge.

Lefebvre, Henri. 1991 [1974]. The production of space. Translated by Donald Nicholson-Smith. Oxford: Blackwell. Original edition, Production de l'espace.

Locke, John. 1980 [1689]. Second treatise of government. Indianapolis: Hackett Publishing Company, Inc. 
London Borough of Newham. 2015. Outline Application 14/01605/OUT. London: London Borough of Newham.

London Borough of Wandsworth. 2011. Outline Planning Application 2009/3575 - Battersea Power Station. London: London Borough of Wandsworth.

MacGregor, B. D., A. E. Baum, C. D. Adams, S.C. Fleming, and J. Peterson. 1985. Land availability for inner city development. Reading: University of Reading

Markowski, Stefan 1978. Study of Vacant Land in Urban Areas. London: Department of Environment.

Marx, Karl. 1990 [1873]. Capital. A Critique of Political Economy. Translated by Ben Fowkes. Edited by New Left Review. Vol. I. London: Penguin Classics.

Massey, Doreen. 1993. "Questions of locality." Geography 78:142.

Massey, Doreen. 1999. "Philosophy and politics of spatiality: some considerations. The HettnerLecture in Human Geography." Geographische Zeitschrift 87 (1):1-12.

Massey, Doreen B. 2005. For space. London: SAGE.

Mayor of London. 2014. The London Strategic Housing Land Availability Assessment 2013. Part of the evidence base for the Mayor's London Plan. London: Greater London Authority.

Mayor of London. 2016. The London Plan. The Spatial Development Strategy for London Consolidated with Alterations since 2011. London: Greater London Authority.

Merrifield, Andy. 2006. Henri Lefebvre: a critical introduction. London: Routledge.

Miles, Matthew B., A. Michael Huberman, and Johnny Saldaña. 2014. Qualitative data analysis : a methods sourcebook. Third edition. ed. Thousand Oaks, Califorinia: SAGE Publications.

Murdoch, Jonathan, and Simone Abram. 2002. Rationalities of planning: development versus environment in planning for housing. Aldershot: Ashgate.

Navarro Cordón, Juan M., and Tomás Calvo Martínez. 1992. Historia de la Filosofía. Madrid: Anaya.

Needham, Barrie. 2006. Planning, law and economics: an investigation of the rules we make for using land. London: Routledge.

Nicholson, D. J. 1982. "Vacant urban land in South Wales: An analysis of the extent and causes of public sector holdings." PhD Thesis, Institute of Science and Technology, University of Wales

Nietzsche, Friedrich, and Soren Kierkegaard. 2007. Repetition and Notes on the Eternal Recurrence: A Comparative Edition (Living Time World Thought): Living Time Media International (LTMI).

Oxley, Michael. 2004. Economics, planning and housing. Basingstoke, UK: Palgrave Macmillan.

Pearsall, Hamil, and Susan Lucas. 2014. "Vacant land: The new urban green?" Cities 40:121-123. doi: https://doi.org/10.1016/j.cities.2013.10.001.

Perin, Constance. 1977. Everything in its place : social order and land use in America. Princeton, N.J.: Princeton University Press. 
Robins, Kevin, Michael Edwards, and Doreen Massey. 2001. "Debates." City 5 (1):77-105. doi: $10.1080 / 13604810120057886$.

Royal Docks Management Authority (RoDMa). 2015. "Forgotten Stories." accessed 25 April 2018. http://www.londonsroyaldocks.com/forgotten-stories/.

Ryan-Collins, Josh, Toby Lloyd, and Laurie Macfarlane. 2017. Rethinking the economics of land and housing. London: Zed.

Ryan, Gery W., and H. Russell Bernard. 2003. "Techniques to Identify Themes." Field Methods 15 (1):85-109. doi: 10.1177/1525822X02239569.

Rydin, Yvonne. 2013. The future of planning: beyond growth dependence. Bristol: Policy Press.

Saint, Andrew. 2013. Battersea. Part 1: Public Commercial and Cultural. Edited by Andrew Saint. Vol. 49, Survey of London. London: Yale University Press on behalf of the Paul Mellon Centre for Studies in British Art.

Sandelowski, Margarete. 1995. "Sample size in qualitative research." Research in Nursing \& Health 18 (2):179-183. doi: 10.1002/nur.4770180211.

Schulze Baing, Andreas. 2010. "Containing Urban Sprawl? Comparing Brownfield Reuse Policies in England and Germany." International Planning Studies 15 (1):25-35. doi: 10.1080/13563471003736910.

Shields, Rob. 1999. Lefebvre, love, and struggle: spatial dialectics. London: Routledge.

Soja, Edward W. 1996. Thirdspace : journeys to Los Angeles and other real-and-imagined places. Cambridge, Mass.: Blackwell.

TCPO. 2015. The Town and Country Planning (Development Management Procedure) (England) Order 2015. The Stationary Office.

The Silvertown Partnership. 2018. "Silvertown London." accessed 27 July 2018. http://www.silvertownlondon.com/.

Thickett, A. 2014. Further Alterations to the London Plan, Inspector's Report. edited by The Planning Inspectorate. London.

Valverde, Mariana 2014. "Time thickens, takes on flesh. Spatiotemporal dynamics in law." In The expanding spaces of law: a timely legal geography, edited by Irus Braverman, Nicholas K. Blomley, David Delaney and Alexandre Kedar. Stanford, California: Stanford University Press.

Watts, Peter. 2016. Up in Smoke: The Failed Dreams of Battersea Power Station. Great Britain: Paradise Road.

William Barnard, G. 2010. "The ever-new flow of time: Henri Bergson's view of consciousness." Journal of Consciousness Studies 17 (11-12):44-61.

Wilson, James Q, and George L Kelling. 1982. "Broken Windows: the police and neighbourhood safety." The Atlantic March 1982.

Yin, Robert K. 2014. Case study research: design and methods. 5th ed. ed. London: SAGE. 